\title{
LEVELS OF PLASMA TESTOSTERONE IN GANDERS AS RELATED TO EGG FERTILIZATION RATE
}

\author{
V. LAZAR, P. JELÍNEK, J. PÍCHA* and DRAHOMÍRA PÍCHOVÁ* \\ University of Agriculture, 66265 Brno, *Research Institute of Feed Supplements \\ and Veterinary Drugs, Pohoří-Chotouň
}

Received September 12, 1983

\begin{abstract}
Lazar, V. P. Jelínek, J. Pícha, Drahomíra Píchová: Levels of Plasma Testosterone in Ganders as related to Egg Fertilization Rate. Acta vet. Brno 53, 1984 : $151-158$.

Testosterone levels in the blood plasma were studied in four strains of ganders of the parent combination of the Ivagees hybrid in the course of the autumn reproduction period (2nd laying cycle). Testosterone was determined by radioimmunoassay using ${ }^{125} \mathrm{I}$ - testosterone as a radioactive ligand. The average concentration of testosterone ranged between 2.93 and $1481 \mathrm{nmol} .1^{-1}$ with a high variability in the individual samplings. In the period of intensive egg laying the relationship was investigated between the level of testosterone in the plasma and fertilization rate of the egg set. In the group of ganders under study, correlation coefficient $r=0.790^{+}$was found. Various levels and tightnesses of the relationship between testosterone level and egg fertilization rate $\left(r=0.859^{++} ; \mathrm{r}=0.594 ; \mathrm{r}=0.687^{+}\right)$were recorded in the individual strains.
\end{abstract}

Geese, testosterone, RIA method, fertility rate of eggs.

The introduction of a two-cycle egg laying in one year prolonged the egg laying period and thus also increased the number of hatching eggs. However, in large breeds, egg laying and fertilization rate are not always in accordance. It is a very important problem which, according to some authors (e. g. Ballay 1975), follows from the fact that the egg laying period in geese was prolonged but that ganders did not adapt enough to this change. That is why methods are searched to evaluate the fertility of ganders. One of these methods is the evaluation of testosterone concentrations in blood which widens the present knowledge and enables to judge the endocrine functions of the gonads contributing to a deeper knowledge of regulatory mechanisms in gander reproduction.

There are not many literary data about testosterone levels in geese. Dittami (1981) studied the behaviour of wild geese in relation to the hormone level in blood (incl. testosterone). Košutzký et al. (1982b) investigated the dynamics of average levels of testosterone in blood plasma during the period from November till September. During this period the testosterone levels had a bi-phasic character with values ranging from 0.82 to $9.59 \mathrm{nmol} .1^{-1}$. The authors did not prove any relationship between the development of the penis and testosterone levels in blood plasma. In their previous study, the present authors (Lazar et al. 1981) observed an increase in the testosterone level in blood plasma of ganders during rearing ( $1-217$ days of age) ranging from 1.504 to 28.793 nmol . $1^{-1}$.

The observed results about the testosterone levels in blood plasma of ganders and their biphasic culmination are essentially in accordance with other literary data (Košutzký et al. 1982b). Jallageas and Assenmacher (1974) found that in the blood plasma of ganders during the year there was a spring peak of testosterone (March and April) and another one in August and September. Tanabe et al. (1981) proved changes in the testosterone levels in cockerels of the age of 28 to 1141 days as well. The first peak of testosterone concentration appeared at the age of 207 days $(3.62 \mathrm{mg} / \mathrm{ml}$ ), then the levels ranged between 1 and $3 \mathrm{mg} / \mathrm{ml}$. L ofts (1975) stated that the sec- 
retion rhythm of testosterone was probably genetically conditioned in the majority of avian species. Zeman (1981) reported that the changes in testosterone levels in poultry males preceeded in time the changes of the semen quality.

\section{Materials and Methods}

In the present study, four strains of the parent combination of geese of the Ivagees hybrid were used (ratio $10: 5$ ). In the course of rearing the parametres of bird density, microclimatic factors and nutritional level were observed, corresponding to requirements determined for the rearing period of geese. Egg fertilization rate was studied during hatching in BA-134 hatchers.

The experimental period lasted from August 20 till January 27, and in the period of intensive egg laying, i. e. from October 19 till December 8, the relationship was studied between the testosterone concentration in the blood plasma of ganders and the fertilization rate of geese eggs. In the period under study, 13 blood samplings were performed in each gander for determinations of basal levels of testosterone and the resulting relationship was evaluated from 8 samplings and 8 egg sets. Blood samples were taken always in the time interval between 10 and 12 hours.

Testosterone concentrations were determined using the radioimmunological assay without extraction (Píchová et al. 1979) using ${ }^{125} \mathrm{I}$ - testosterone as radioactive ligand (Ver eš et al. 1979). The resulting values were given in $\mathrm{nmol} .1^{-1}$.

The basic statistical characteristics were calculated in basal values of plasma testosterone and fertility rate of egg sets, i. e. $\bar{x}=$ mean, $s x=$ standard deviation, $s \bar{x}=$ mean error, $v x=$ coefficient of variation), and correlation ( $r=$ correlation coefficient) and regressior analyses $\left(y^{\prime}=a+b x-\right.$ - regression straight line) were carried out.

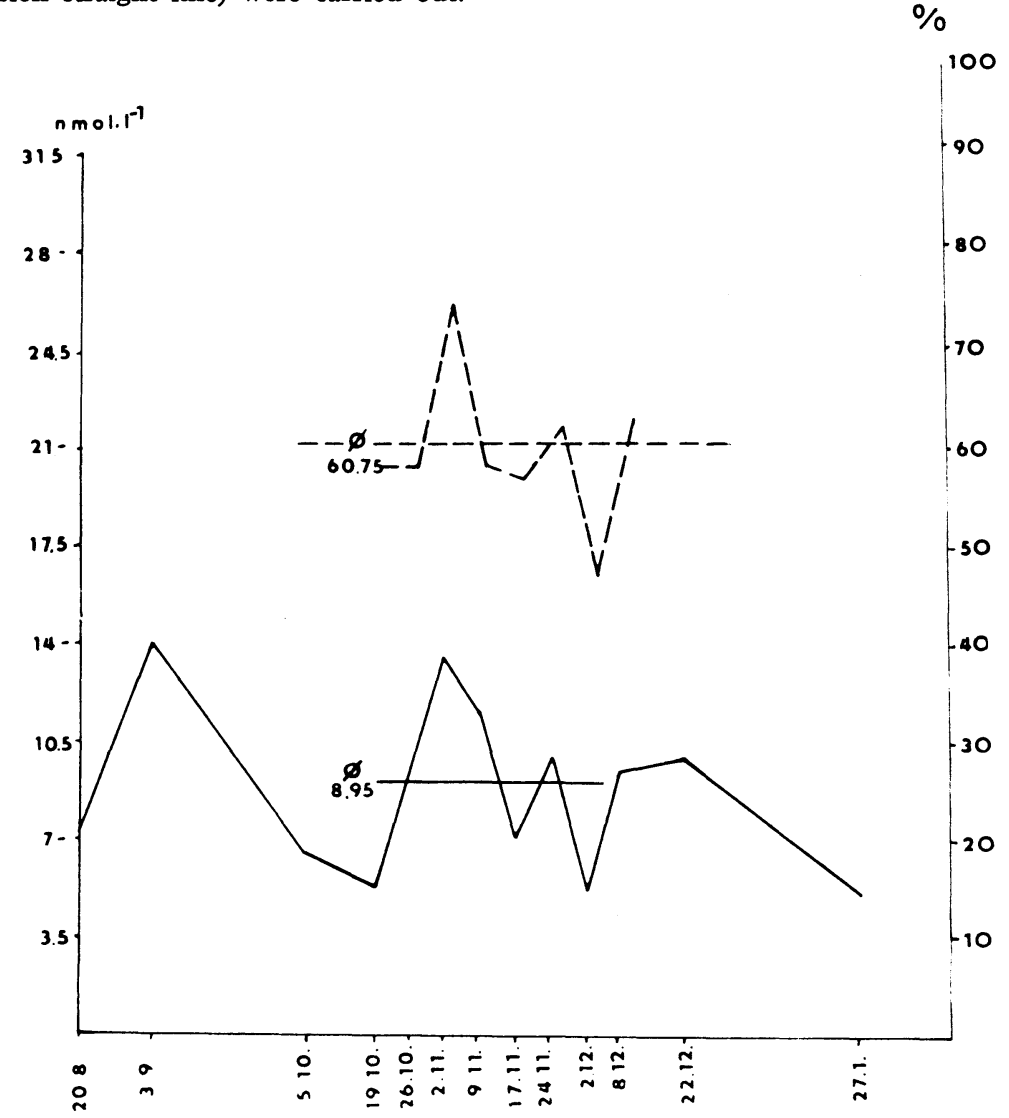

Fig. 1. Summarized values of testosterone concentration in the investigated group of ganders and egg fertilization rate. 


\section{Results and Discussion}

The basal levels of plasma testosterone in gander during the period from August to January are given in Tab. 1. The range of mean values $\left(5.05-14.14 \mathrm{nmol}^{-1} \mathrm{1}^{-1}\right)$ is higher than that given by Košutzký et al. (1982b) during the period from November to September. The high values of the coefficient of correlation show that there are individual differences among the ganders and that the course is biphasic with regard to the time intervals investigated. In Tab. 1 and Figs.

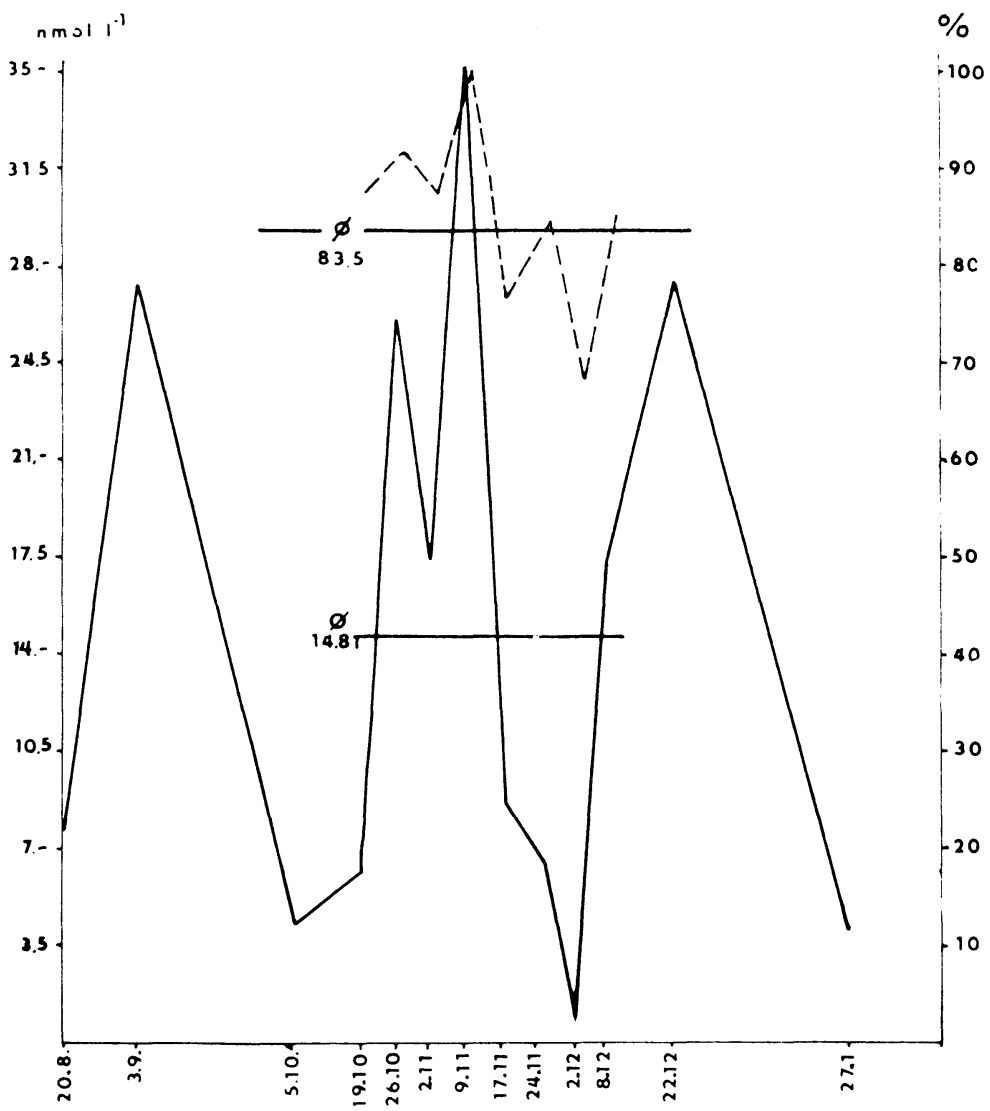

Fig. 2. Values of testosterone concentrations in gander 1/3004 and egg fertilization rate.

$1-5$, certain phases of culmination of testosterone concentrations in blood plasma are evident. In the strains of the group of ganders studied (Fig. 1) a biphasic culmination with peaks at the beginning of September and the beginning of November appeared, similarly as in the investigations of Košutzký et al. (1982). Despite the different period of investigations and different conditions of the environment (in the present study a stimulation light regime as compared with a natural light regime of other authors), the culmination of testosterone in blood plasma in the autumn, i. e. in August and September, is the same as observed by Jalla- 
Table 1

Basal levels of plasma testosterone in the course of the autumn reproduction cycle (nmol . $\left.1^{-1}\right)$

\begin{tabular}{|c|c|c|c|c|c|}
\hline \multirow{2}{*}{ Time of sampling } & \multicolumn{4}{|c|}{ Strain/gander } & \multirow{2}{*}{$\Sigma$} \\
\hline & $1 / 3004$ & $2 / 3102$ & $3 / 3013$ & $4 / 3022$ & \\
\hline $\begin{array}{l}\text { Aug. } 20 \\
\text { Sept. } 3 \\
\text { Oct. } 5 \\
\text { Oct. } 19 \\
\text { Oct. } 26 \\
\text { Nov. } 2 \\
\text { Nov. } 9 \\
\text { Nov. } 17 \\
\text { Nov. } 24 \\
\text { Dec. } 2 \\
\text { Dec. } 8 \\
\text { Dec. } 22 \\
\text { Jan. } 27\end{array}$ & $\begin{array}{r}7.68 \\
27.45 \\
4.22 \\
6.36 \\
25.99 \\
17.38 \\
35.25 \\
8.68 \\
6.70 \\
0.88 \\
17.24 \\
27.34 \\
4.10\end{array}$ & $\begin{array}{r}0.80 \\
3.49 \\
3.50 \\
0.49 \\
1.75 \\
10.50 \\
0.64 \\
2.80 \\
1.16 \\
1.67 \\
4.45 \\
2.26 \\
5.06\end{array}$ & $\begin{array}{r}7.77 \\
8.64 \\
12.19 \\
10.69 \\
6.45 \\
21.02 \\
3.57 \\
4.29 \\
12.47 \\
7.68 \\
3.79 \\
2.40 \\
2.65\end{array}$ & $\begin{array}{r}14.09 \\
17.01 \\
6.48 \\
3.91 \\
3.10 \\
5.31 \\
7.88 \\
12.56 \\
19.72 \\
10.00 \\
12.25 \\
7.55 \\
8.65\end{array}$ & $\begin{array}{r}7.58 \\
14.14 \\
6.59 \\
5.36 \\
9.32 \\
13.54 \\
11.83 \\
7.08 \\
10.01 \\
5.05 \\
9.43 \\
9.87 \\
5.11\end{array}$ \\
\hline \multicolumn{6}{|l|}{ Characteristics } \\
\hline $\begin{array}{l}\bar{x} \\
s x \\
s \bar{x} \\
v x\end{array}$ & $\begin{array}{r}14.56 \\
11.25 \\
3.12 \\
77.25\end{array}$ & $\begin{array}{r}2.97 \\
2.69 \\
0.75 \\
90.81\end{array}$ & $\begin{array}{r}7.97 \\
5.23 \\
1.45 \\
65.64\end{array}$ & $\begin{array}{r}9.89 \\
5.03 \\
1.40 \\
50.85\end{array}$ & $\begin{array}{r}8.84 \\
3.06 \\
0.85 \\
34.61\end{array}$ \\
\hline
\end{tabular}

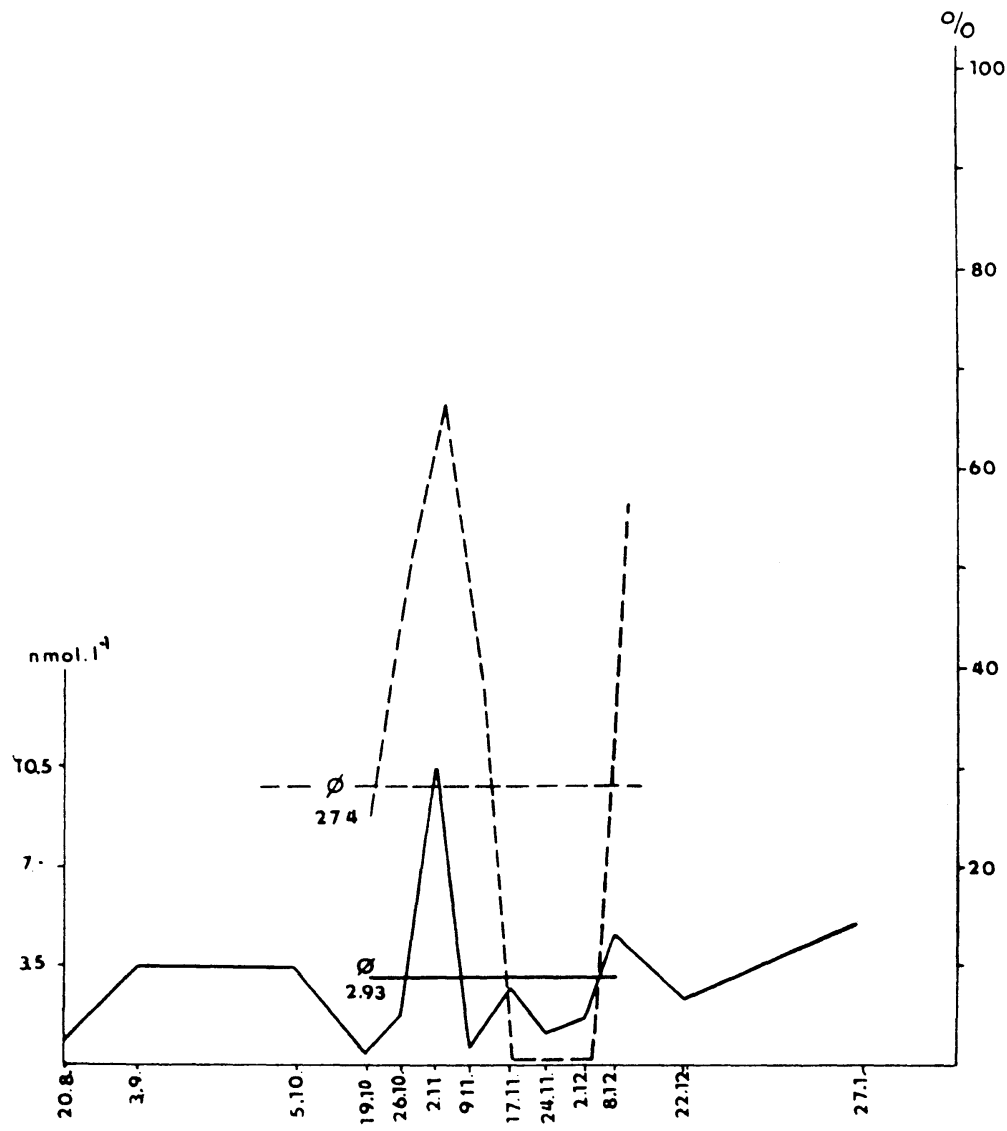

Fig. 3. Values of testosterone concentrations in gander $2 / 3102$ and egg fertilization rate. 


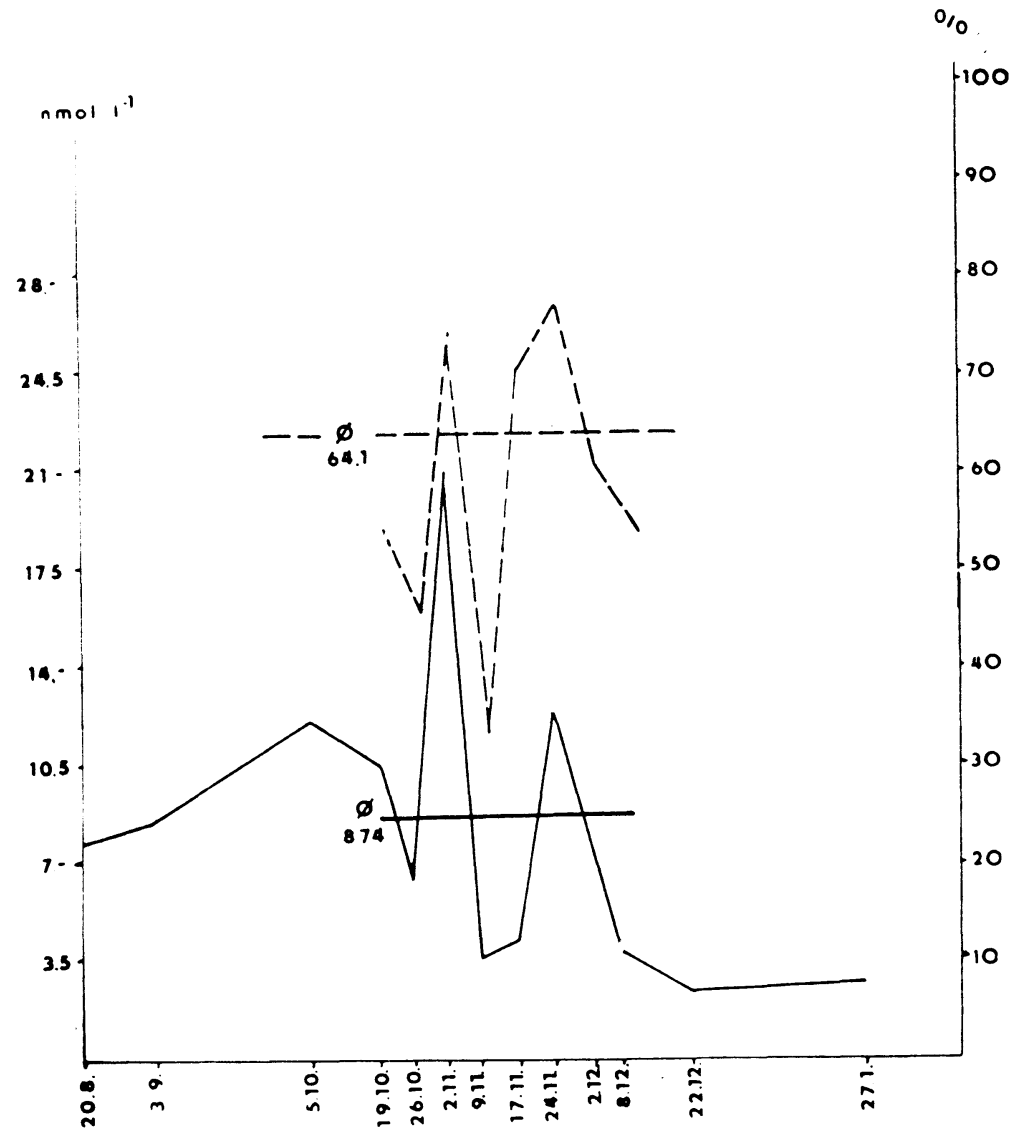

Fig. 4. Values of testosterone concentrations in gander 3/3013 and egg fertilization rate.

Table 2

Summarized statistical characteristics and correlation analysis of testosterone concentration in the group of ganders under study (for the period from October 19 till December 8 ) and egg fertilization rate

\begin{tabular}{|c|c|c|}
\hline \multirow{2}{*}{ Characteristics } & \multicolumn{2}{|c|}{ Indicator } \\
\hline & $\begin{array}{l}\text { testosterone concentration } \\
\text { nmol } .1^{-1}\end{array}$ & egg fertility rate \% \\
\hline $\begin{aligned} & \bar{x} \\
& s x \\
& s \bar{x} \\
& v x \\
& y^{\prime}= a+b x\end{aligned}$ & $\begin{array}{r}8.95 \\
2.98 \\
1.05 \\
33.29 \\
\\
\quad y^{\prime}=60 .\end{array}$ & $\begin{array}{r}60.11 \\
8.06 \\
2.85 \\
13.40\end{array}$ \\
\hline
\end{tabular}




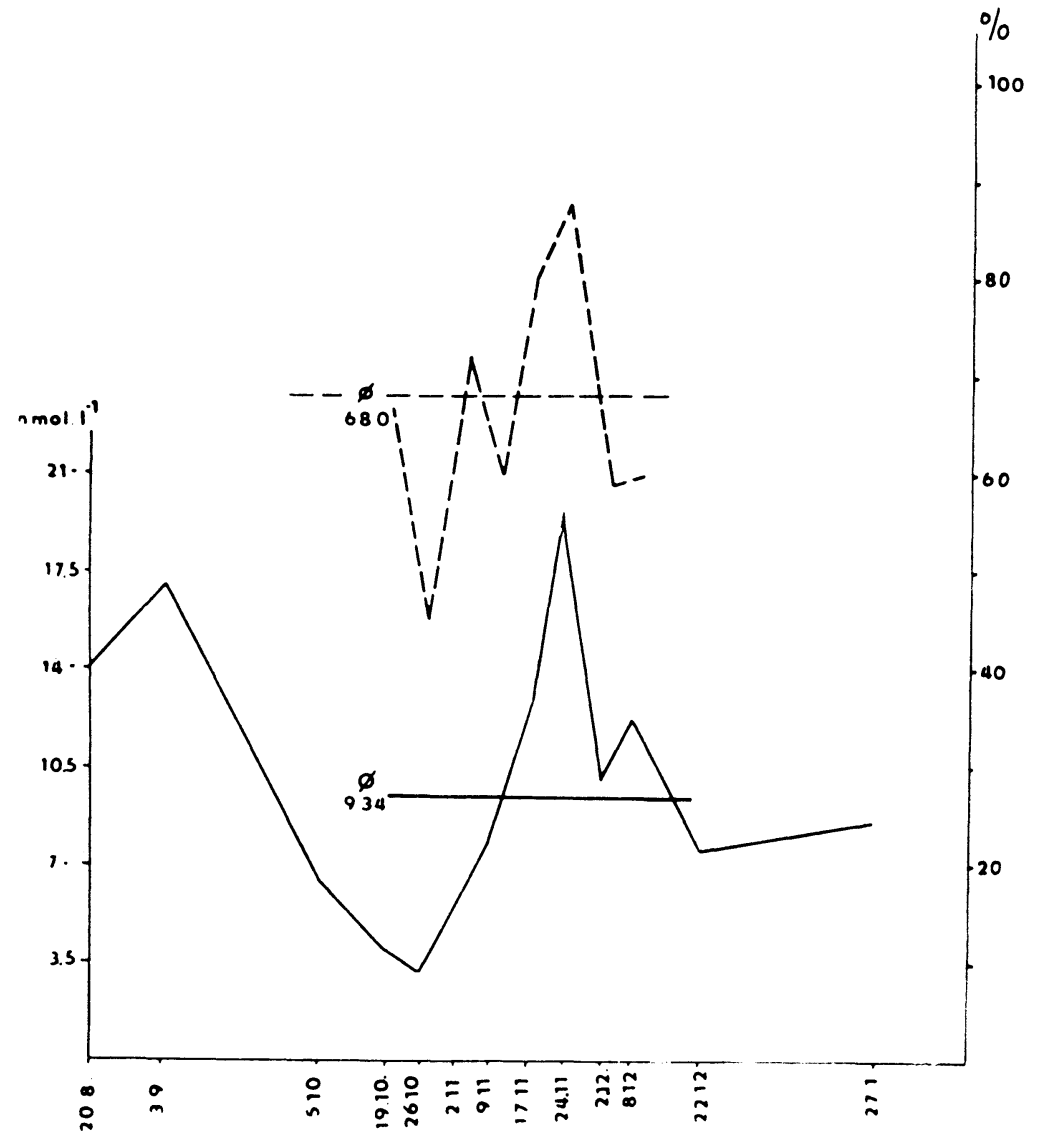

Fig. 5. Values of testosterone concentrations in gander 4/3122 and egg fertilization rate.

geas and Assenmacher; (1974) and Košutzký et al. (1982b). The different secretion rhythm of testosterone in the individual ganders can probably be explained by the findings of Lofts (1975).

In the graphic illustrations of the changes of testosterone concentrations in the blood plasma and of the fertilization rate of egg sets (Figs. 1-5) it is evident that there is a certain relationship between these factors. This relationship is proved in the level of coefficients of correlation and regression straight lines given in Tab. 2 and Tab. 3. It is evident that the tightness of the relationship increased with the "quality of the gander", e. g. in gander 1/3004 in the period studied the average testosterone concentration was found to be $14.81 \mathrm{nmol} .1^{-1}$ and the average fertilization rate of eggs was $85.29 \%$ which is reflected in the value of the coefficient of correlation quoted by Zeman (1981).

Even though the present results are only of an orientation character, especially in connection with the limited number of investigations and in spite of the complexity of regulatory mechanisms on which the level of testosterone in plasma depends, it is evident that the analysis of hormonal relationships is a perspective parameter utilizable in modern poultry rearing. 
Table 3

Summarized statistical characteristics and correlation analysis of testosterone concentration in the individual ganders (for the period October 19 till December 18) and egg fertilization rate

\begin{tabular}{|c|c|c|c|}
\hline \multirow{2}{*}{ Strain/gander } & \multirow{2}{*}{ Characteristics } & \multicolumn{2}{|c|}{ Indicator } \\
\hline & & $\begin{array}{c}\text { testosterone concentration } \\
\text { nmol } .1^{-1}\end{array}$ & $\begin{array}{c}\text { fertilization rate of eggs } \\
\%\end{array}$ \\
\hline $1 / 3004$ & $\begin{array}{c}\bar{x} \\
s x \\
s \bar{x} \\
v x \\
r \\
y^{\prime}=a+b \cdot x\end{array}$ & $\begin{array}{rrr}14.81 & & \\
11.49 & & \\
4.06 & & \\
77.59 & \\
& & \\
& y^{\prime}=0.8 \\
& & 0.2\end{array}$ & $\begin{array}{r}85.29 \\
9.44 \\
3.34 \\
11.07 \\
0.00001 x\end{array}$ \\
\hline $2 / 3102$ & $\begin{array}{c}\bar{x} \\
s x \\
s \bar{x} \\
v x \\
r \\
y^{\prime}=a+b \cdot x\end{array}$ & $\begin{array}{r}2.93 \\
3.31 \\
1.17 \\
113.05 \\
\\
\quad y^{\prime}=0.05\end{array}$ & $\begin{array}{rr} & 29.75 \\
27.42 \\
\\
\\
\\
\\
9.70 \\
92.16 \\
\end{array}$ \\
\hline $3 / 3013$ & $\begin{array}{l}\bar{x} \\
s x \\
s \bar{x} \\
v x \\
y^{\prime}=\stackrel{r}{a}+b \cdot x\end{array}$ & $\begin{array}{l}8.74 \\
5.93 \\
2.10 \\
67.79 \\
\\
\quad y^{\prime}=0.16\end{array}$ & .0002 \\
\hline $4 / 3022$ & $\begin{array}{c}x \\
s x \\
s \bar{x} \\
v x \\
r \\
y^{\prime}=a^{x+b} \cdot x\end{array}$ & $\begin{array}{l}9.34 \\
5.53 \\
1.95 \\
59.16 \\
\\
\quad y^{\prime}=0.18\end{array}$ & $\begin{array}{r}66.48 \\
13.50 \\
4.77 \\
20.31 \\
+\quad 0.00002\end{array}$ \\
\hline
\end{tabular}

Hladiny plazmatického testosteronu u houserů ve vztahu $k$ oplozenosti vajec

Ve čtyřech kmenech byly u houserů rodičovské kombinace hybrida Ivagees $\mathrm{v}$ průběhu podzimního reprodukčního období (2. snáškový cyklus) sledovány hladiny testosteronu $\mathrm{v}$ krevní plazmě. Testosteron byl stanoven radioimunologickým postupem za použití ${ }^{125}$ I-testosteronu jako radioligandu. Prủměrná koncentrace testosteronu se pohybovala v rozmezí 2,93 až $14,81 \mathrm{nmol} \cdot 1^{-1} \mathrm{~s}$ vysokou variabilitou jednotlivých odběrů. $\mathrm{V}$ období intenzívní snášky byl zjištován vztah mezi hladinou testosteronu $\mathrm{v}$ plazmě a oplozeností násadových vajec. $\mathrm{U}$ sledovaného souboru houserů byla zjištěna úroveň korelačního koeficientu $r=0,790^{+}$. $\mathrm{V}$ jednotlivých kmenech byly zaznamenány rozdílné úrovně a těsnosti vztahu hladin testosteronu a oplozenosti vajec $\left(r=0,859^{++} ; r=0,594 ; r=0,611 ; r=\right.$ $=0,687^{+}$).

\section{Уровни плазменного тестостерона у гусаков по огношениюо к оплодотворению яиц}

В четырех трибах гусаков родительской комбинации гибрида Ивагеес в течение осеннего периода репродукции (второй цикл снашивания) проводились исследования тестостерона в кровяной плазме. Тестостерон опре- 
деляли радиоиммунологическим методом при использовании 125 I - тестостерона в качестве радиолиганда. Средняя концентрация тестостерона колебалась в пределах 2,93-14,81 нмоль.л-1 с большой изменчивостью отдельных отборов. В период интенсивного снашивания устанавливали отношение между уровнем тестостерона в плазме и оплодотворенностью яиц под наседкой. У исследуемой группы гусаков был установлен уровень коэффициента корреляции $\mathbf{r}=0,790^{+}$. В отдельных трибах отмечался разный уровень и плотность отношения уровней тестостерона и оплодотворенности яй $(\mathrm{r}=$ $=0,859++; \mathrm{r}=0,594 ; \mathrm{r}=0,611 ; \mathrm{r}=0,687+)$.

\section{References}

BALLAY, A.: A ludak korának és a termelésben töltött idönek hatásai a ládtojások termékenységére és a korai embionális elhalásokra. Baromfiipar, 22, 1975: 349-352.

DITTAMI, J. P.: Seasonal changes in the behavior and plasma titers of various hormones in Barheaded Geese, Anser indicus. Z. Tierpsychol., 55, 1981: 289-324.

JALLAGEAS, M. - ASSENMACHER, I.: Thyroid-gonadal interactions in the male domestic duck in relationship with sexual cycles. Gen. comp. Endocrinol, 22, 1974: 13-20.

KOŠUTZKÝ, J. - ZEMAN, M. - BOBÁKOVÁ, E. - UHRÎN, V. - ADAMEC, O.: Štúdium regulačných mechanizmov $v$ reprodukcii hydiny (I. čast' - testosterón). Project report VÚCHŠH Ivanka pri Dunaji, 1982, p. 62.

KOSUTZKÝ, J. - BOBÁKOVÁ, E. - ZEMAN, M. - Š́RNIKOVÁ, B.: Hladiny plazmatického testosterónu u gunárov v priebehu reprodukčnej sezóny. Živ. výroba, 27, 1982: 695-700.

LAZAR, V. - PÍCHA, J. - PÍCHOVÁ, D.: Plasma testosterone, estradiol, progesterone and thyroxine concentration in the course of goose rearing. Sci. Agric. Bohemoslov., 13, 1981: $221-230$.

LOFTS, B.: Enviromental control of reproduction. Symp. Zool. Soc. London, 35, 1975: 177-197.

PÍCHOVÁ, D. - ŚORFOVÁ, J. - PÍCHA, J.: Stanovení progesteronu v plazmè. In: Sborník III. vědecké pracovní dny o radioimunoanalýze v Martině, $1979, \mathrm{p} .11$.

TANABE, Y. - NAKAMURA, T. - TANASE, H. - DOI, O.: Comparisons of Plasma LH, Progesterone, Testosterone and Estradiol Concentrations in Male and Female Chickens from 28 to 1141 Days of Age. Endocrinol. Japon., 28, 1981: 605-613.

VEREŠ, K. - PÍCHOVÁ, D. - HOLIK, J. - SIEGLEROVÁ, V.: Syntéza radioligandů 125I pro RIA některých steroidních hormonủ. In: Sborník III. vědecké pracovní dny o radioimunoanalýze v Martině, 1979, p. 8.

ZEMAN, M.: Regulačné mechanizmy $\mathrm{v}$ reprodukcii samcov hydiny. $\mathrm{PhD}$ Thesis, Ivanka pri Dunaji, 1981, p. 126. 